\title{
REFLEXÕES SOBRE A NATUREZA DO PODER POLÍTICO:O PROBLEMA DA HIPOCRISIA
}

Flávio Eduardo Silveiral

O problema da hipocrisia constitui um relevante elemento a ser considerado nas reflexões sobre a natureza do poder político. Contudo, este problema tem sido negligenciado nas análises políticas. De um lado, por razões metodológicas. Estudar hipocrisia significa penetrar no terreno difícil e espinhoso do que é omitido, dissimulado, escondido e negado. Embora as pessoas, em geral, reconheçam a forte presença da hipocrisia na vida social e política, este reconhecimento é sempre exteriorizado: na fala do sujeito, as atitudes hipócritas fazem parte do mundo dos outros.

É próprio da atitude hipócrita mentir duas vezes: mentir por ser hipócrita e mentir por não poder ser publicamente vista como hipócrita. As intenções conscientes e as versões dos acontecimentos afirmadas explicitamente pelo agente são produto de um permanente trabalho de racionalização, através do qual ele busca tornar aceitável para si e para os demais atos que são considerados inaceitáveis de acordo com os valores morais que ele mesmo afirma publicamente.

De outro lado, o modo como grande parte dos analistas, filósofos e cientistas políticos concebem o mundo político conduz à percepção deste objeto como

${ }^{1}$ Doutor em Ciência Política pela USP, professor na Pontifícia Universidade Católica do Rio Grande do Sul e diretor da Meta Pesquisas. 
pouco digno de estudo. As ações hipócritas encontram-se, na maior parte das vezes, ausentes, na teoria política. Em análises realistas da política e da natureza humana, como as de Maquiavel, e críticas da razão política, como as de Foucault, o problema da hipocrisia constitui um elemento central das relações de poder. Mas, a maior parte da tradição do pensamento político desconsidera ou atribui pouca importância ao problema. As preocupações dominantes estão voltadas ao debate sobre as melhores formas de governo, entendidas como aquelas que possibilitam a realização da finalidade da política de assegurar a justiça, o bem e a felicidade dos homens. O grosso da produção intelectual persegue o objetivo de descobrir as regras jurídicas e os mecanismos institucionais que tornam possível o bom governo, ou de construir explicações convincentes sobre os fundamentos da obrigação política. Nesta perspectiva, a hipocrisia está dissociada da política. Ela faz parte da má política, das más formas de governos, dos governantes desonestos e mentirosos. A questão da hipocrisia é deslocada para o plano moral da natureza dos regimes e das intenções dos agentes. Desconsidera-se, assim, a eficácia instrumental do recurso hipócrita e sua presença e importância no jogo político.

Este ensaio objetiva refletir sobre a relação entre hipocrisia e poder. Serão abordadas questões de caráter conceptual, reconstituídas as discussões sobre o significado das concepções de verdade e hipocrisia e analisadas as relações entre poder, saber, racionalidade e hipocrisia.

\section{A noção de hipocrisia}

O termo hipocrisia era utilizado na Grécia antiga com um significado semelhante ao usualmente empregado na atualidade: procedimento similar ao de um ator (do grego "hypocritás"); isto é, aquele que intencionalmente age de modo simulado; produz atos e palavras em desconformidade com o que ele pensa e esconde a natureza desta representação; age de forma enganosa, com o objetivo não revelado de produzir determinados resultados, diferentes daqueles que seriam decorrência de um comportamento não falsificado.

Este termo não aparece freqüentemente nos escritos antigos, mas o mesmo não pode ser dito sobre a noção relativa a ele, muito familiar aos pensadores da antigüidade. Diferenciados critérios para a definição da ação hipócrita e para a identificação do perfil do agente hipócrita são delineados nos escritos antigos.

$\mathrm{Na}$ filosofia grega antiga há duas linhas de pensamento contrastantes. $\mathrm{O}$ pensamento de Platão e o de Aristóteles formalizam, sistematizam e desenvolvem 
uma concepção de verdade substancialmente distinta da tradições anteriores, da escola eleática e, sobretudo, da escola sofística. Estas escolas haviam elaborado idéias que, em maior ou menor medida, relativizavam a possibilidade de conhecimento da verdade e questionavam as fronteiras entre verdade e falsidade.

Zenão de Eléia introduz, a partir do esquema explicativo de seu mestre, Parmênides, uma nova abordagem do problema da verdade. Parmênides, nada relativista, acredita na possibilidade de conhecimento da verdade através da via racional da evidência. Para ele, somente é possível conhecer o ser (o que é), pois o não-ser (o que não é) não existe, não se pode pensar nem dizer. O que é tido e dito como não-ser em alguma medida é: não deixa de fazer parte do Ser, uma vez que este_pleno e completo como unidade absoluta que congrega tudo no espaço e no tempo.

Zenão leva o monismo parmediano ao limite, mostrando, dialeticamente, o seu contrário. Da idéia de que só se pode falar do ser e do não-ser não se pode enunciar nada, conclui que o erro é impossível. Isto é, o não-ser não é erro, pois nada é. Uma proposição que não é verdadeira corresponde a um conjunto de signos sem sentido. Todas as proposições são verdadeiras, não por que são idênticas, mas porque no podem ser definidas nos termos da oposição falso/verdadeiro.

Os argumentos de alguns sofistas são ainda mais mordazes na crítica à apologia da verdade. Protágoras de Abdera sustenta a impossibilidade de se alcançar uma verdade absoluta e universal. No seu entender, o homem é a medida de todas as coisas, das que são enquanto são e das que não são enquanto não são. Isto é, o ser e o não-ser existem nas coisas em geral, portanto, há pluralidade. As coisas são de um modo enquanto não se transformam: assim é introduzida a noção de movimento. E são os homens que, a partir das suas percepções das coisas, definem suas verdades, que não são incontestáveis nem eternas, mas se modificam conforme as circunstâncias e o tempo.

Górgias de Leôncio leva ao extremo a perspectiva relativista. Em sua polêmica com os eleatas sustenta que não há ser; o ser, entendido à maneira eleática como imutável, eterno e infinito não existe, uma vez que o infinito não está em parte alguma, nem em si em qualquer outro lugar. Se o ser existisse não seria cognoscível, pois somente poderia ser apreendido pelo pensamento e o pensado é distinto do que é. Se o ser fosse cognoscível não seria comunicável, em função da diferença entre o pensado e a expressão do que se pensa.

O pensamento de Platão e o de Aristóteles divergem totalmente desta tradição. Para os autores a verdade é o oposto da falsidade e do erro, é o absolutamente 
certo e o universalmente válido. A verdade é o objeto da busca incessante do autêntico filósofo. Para alcançá-la, ele deve afastar as paixões, os temores e as imaginações de toda a sorte que agitam e desorganizam o pensamento e adotar o espírito sensato do sábio e o princípio lógico da razão. Deve guiar o seu pensamento de modo reto, "dizendo coisas verdadeiras, com base em premissas da mesma espécie, para chegar a conclusões da mesma natureza"(Aristóteles, 1959).

O que torna possível a falsidade é supor o não-ser como ser. Como pensar e falar do que absolutamente não é_sem cair em inevitáveis contradições? Somente o fato de considerar algo como não-ser, implica em admitir a sua existência. Mas se não for admitida a sua existência não é possível decifrar a sua natureza. É preciso, assim, ousar conhecer o não ser como ele realmente é. O não-ser não corresponde a nada, como afirmavam os eleatas; embora ele seja o contrário do ser ele também tem um ser: ele é o outro. O ser e o outro se associam e se penetram mutuamente. "Assim, o outro, participando do ser, é, pelo fato desta participação; sem, entretanto, ser aquilo que participa”(Platão,1961).

O não-ser gera a opinião falsa e o discurso falso, que enunciam ou representam não-seres, como imagens cópias e simulacros. "É neste abrigo" - diz Platão - "que o sofista se refugiou"(Platão, 1961). Na obscuridade do não-ser, ele consegue parecer sem ser, dizer algo que não é, mas parece verdade, sem cair em contradições. A aparente sabedoria do sofista é produto da arte da mimética: produz imitações e homônimos das realidades, criando simulacros e falsificações. O aparente saber se esconde na astuciosa forma de realizar a controvérsia: através de breves argumentos e refutações pontuais busca desestruturar a lógica do raciocínio do interlocutor, conduzindo-o a contradições, paradoxos, conclusões insustentáveis, erros lógicos, solecismos, e outros descaminhos, analisados detalhadamente por Aristóteles em “Dos Argumentos Sofísticos”(Aristóteles,1973).

O sofista é, assim, definido como hipócrita. Produz um saber falso e não o apresenta enquanto tal, diz ter ciência do que tem apenas opinião, tem ciência da sua ignorância em relação a assuntos sobre os quais se dá ares de sábio, e utiliza o seu saber para fins mercenários, totalmente distintos dos fins desinteressados do verdadeiro filósofo.

Esta imagem do sofista como hipócrita parece contradizer o escrito "Hípias Menor" em que Platão sustenta a impossibilidade da ação intencionalmente falsa, uma vez que para se poder enganar os demais é preciso saber e inteligência, qualidades próprias dos melhores, que não seriam falsos, nem praticariam o mal, voluntariamente(Platão,1986). No hipotético diálogo de Platão, em que esta tese é 
defendida por Sócrates contra a proposição inversa do sofista Híppias, há , contudo, uma armadilha. Sócrates sustenta a impossibilidade da falsidade, mas através dos argumentos que utiliza no próprio diálogo, acusa ironicamente seu interlocutor sofista de hipócrita. Isto é particularmente perceptível no jogo de argumentos através do qual Sócrates estimula Híppias a gabar-se por seus inúmeros conhecimentos (o melhor em cálculo, em aritmética, em geometria, etc.) e, posteriormente, o conduz a raciocínios que tornam impossível negar que a figura do gabarola coincide com a do impostor.

Em "Sofista" Platão inverte os termos da discussão sobre a verdade: os sofistas negam a própria existência da verdade, não porque seja possível uma outra concepção sobre falso/verdadeiro, mas porque eles mesmos são falsos sábios e produzem saber falso. Eles necessitam relativizar as fronteiras entre o verdadeiro e o falso, dizendo que um é o outro e vice-e-versa, para eles mesmos poderem se ocultar nesta confusão, dissimulando o que realmente são.

O sofista é, para o pensamento platônico e aristotélico, totalmente distinto do político. A mais nobre de todas as ciências, a política, tem como finalidade suprema a justiça e a felicidade dos homens. Assim como o pastor guia e cuida do seu rebanho, o político tem por objetivo conduzir homens no sentido do bem comum. Tal arte exige certas qualidades. É próprio ao político ser virtuoso, honrado, sábio e justo. Para realizar seus objetivos, deve dirigir os homens através do consentimento e não da força, conforme a ênfase de Platão (1946), visando o interesse geral e não o particular, de acordo com o que ressalta Aristóteles(1985).

Entretanto, também há entre os políticos àquele chamado por Platão de "arauto" ou de "orador popular", que se sustenta pelo aplauso das multidões e parece ser um grande estadista, mas de fato é o mais mágico de todos os sofistas. Aristóteles define mais precisamente este falso político como demagogo. Ele atribui ao termo, que significava "guia do povo", a conotação pejorativa de dirigente popular interesseiro e enganoso. O demagogo adula o povo através de discursos e medidas que facilmente obtêm simpatia popular e utiliza o apoio recebido, para, em situações particularmente favoráveis, incitar as multidões contra o governo e, por este meio, alcançar o poder político. Quando os demagogos controlam o poder, afastam-se do povo e comprometem seriamente os interesses dos ricos, que se voltam contra eles. Para governarem na situação de desordem provocada, desrespeitam as leis, utilizam a força, concentram poderes e tornam-se tiranos.

A filosofia platônica e aristotélica é criticada pela escola cínica. Esta retoma as idéias eleáticas e sofísticas de questionar a relação verdade/falsidade. Antístenes, 
fundador da escola, rejeita o método platônico de discutir, refutar erros e definir. No seu entender, a discussão não é possível ou porque os interlocutores pensam a mesma coisa, e neste caso estão de acordo, ou pensam coisas diferentes e a discussão não tem sentido. A impossibilidade do erro é sustentada através do argumento de Zenão: não se pode pensar senão aquilo que é, e o erro consistiria em pensar o que não é. E a definição_considerada impossível, porque ou bem se trata de uma essência composta, e neste caso pode-se enumerar os elementos primitivos que a compõem, ou então é essência simples, e somente se pode dizer a que se parece. Opondo-se ao intelectualismo do pensamento filosófico de Platão, afirma que a virtude está nos atos, mais do que nas palavras. Ela consiste antes de tudo na independência e na liberdade. Para realizar a sua atividade de forma plena, o sábio deve bastar-se a si mesmo.

O cínico que se tornou mais conhecido, Diógenes de Sínope, segue esta tradição. Vestimenta simples, comendo qualquer coisa, dormindo em qualquer lugar, sem casa, nem cidade, como um mendigo errante, quer mostrar que se encontra liberdade reduzindo ao mínimo as necessidades. Despreza tudo que é convencional e não natural, todas as leis e regras morais que considera como contrárias à natureza. Ao invés de elaborar uma grande teoria, como a do modelo platônico, busca dizer coisas através da ação, descartando o jogo do discurso.

Critica a hipocrisia da filosofia bem comportada que não vive o que diz. A sua insolência anti-convencionalista se expressa em ditos espirituosos e demonstrações práticas, que tomam a forma de lendas e anedotas. Mostra o seu desprezo pelo poder e pelos poderosos através de respostas insolentes. Diógenes denuncia através de ações pontuais de elevado efeito simbólico, a mesquinharia, o artificialismo, a hipocrisia e a bazófia da sociedade ateniense. Define-se como um cidadão do mundo, e afirma ser seu domicílio um tonel. Recomenda que não se deve seguir as leis da cidade, mas as da virtude e da natureza. Sustenta a supressão de todas as barreiras que separam os homens. Mas não acredita que isto seja possível através da participação política, pois considera viciado o jogo do poder e percebe o povo dominado por uma insana valorização de bens sem valor.

A escola céptica (Pirro, Timom) também opõe-se ao pensamento de Platão e de Aristóteles. Sua crítica está centrada na pretensão destes filósofos, entre outros, terem encontrado o que julgam ser o critério de verdade. Para os cépticos, nem as sensações nem os juízos conduzem quer a verdade quer ao erro. As sensações são cambiantes e os juízos convencionais. A crença em um saber verdadeiro, único e absoluto leva inevitavelmente a erros. A forma mais sábia de proceder_suspender os juízos e permanecer na indiferença. A dúvida conduz ao bem e a felicidade. 
O pensamento de Maquiavel também representa uma ruptura com a tradição platônica/aristotélica. Ao invés de elaborar, ao estilo platônico, modelos ideais de Repúblicas e de Estados, examina os regimes e os governos a partir da prática política efetivamente realizada pelos governantes. Não define o político de maneira abstrata, tendo em vista os fins da política, mas de maneira concreta em função das suas ações. Não considera uma ação boa ou má em virtude da sua essência. Utiliza o próprio critério da lógica do poder: qualifica a ação tendo em vista a sua eficácia, sua capacidade de atingir fins desejados.

Maquiavel mostra as técnicas hipócritas do poder praticadas na sua época. Não considera a hipocrisia um atributo do falso político (como no caso da figura aristotélica do demagogo), mas um recurso usualmente utilizado na atividade política realmente realizada. No seu entender, o governante necessita, para conquistar a estima do povo, parecer bondoso, humano, piedoso, íntegro e honesto, ainda que não possua tais qualidades ou que seja levado em função dos seus interesses a agir de modo diverso. É próprio da arte política a utilização de estratagemas como ressaltar os benefícios feitos e ocultar falhas e erros, e atribuir aos outros as coisas odiosas e reservar para si as enaltecedoras. Ou o uso de técnicas violentas e, inclusive cruéis, para inspirar temor e impedir revoltas. Podem ser utilizados os mais variados meios para os fins de conservação do poder. Afirma Maquiavel “...se um príncipe pretende conquistar e manter um Estado, os meios que empregar serão sempre julgados honrosos e por todos louvados, porque o vulgo sempre se deixa levar pelas aparências e pelos resultados"(Maquiavel, 1976).

A hipocrisia é considerada, assim, um instrumento importante no jogo do poder, que pode ser utilizado pelos governantes segundo as suas necessidades e os seus objetivos de êxito. Neste sentido, Maquiavel afirma explicitamente as vantagens advindas da ação hipócrita: inúmeras "promessas foram tornadas irritas e vãs pela infidelidade dos príncipes, e aquele que, com mais perfeição, soube agir como raposa, saiu-se melhor". Daí que "um senhor prudente não pode, nem deve guardar a sua palavra, quando isto for prejudicial aos seus interesses", sendo necessário "saber bem disfarçar esta qualidade e ser grande simulador e dissimulador"(Maquiavel, 1976). Ao recomendar o uso do recurso hipócrita, Maquiavel faz o que a atitude hipócrita jamais poderia fazer: declarar-se publicamente como tal. Por isto Voltaire afirmou que "se Maquiavel tivesse tido um príncipe como discípulo, a primeira coisa que teria lhe recomendado era escrever um livro contra o maquiavelismo"(Greene, 2000).

O pensamento iluminista, que pretende libertar o conhecimento humano do domínio das explicações místicas e religiosas, e fornecer a ele fundamentos racio- 
nais e científicos, acredita, tal como a tradição platônica/aristotélica, na possibilidade de conhecimento da verdade objetiva e universalmente válida através do método racional analítico próprio da ciência. Aposta nas potencialidades da razão enquanto instrumento de libertação do homem. A razão é utilizada, como na obra de Rousseau, para o questionamento da desigualdade social e da legitimidade do regime absolutista, e para elaboração de novos e legítimos fundamentos de obrigação política. Volta-se, tal como os escritos de Montesquieu, para a construção das bases institucionais de um novo regime fundado nas leis, que assegure maior igualdade e felicidade aos homens.

Na perspectiva das Luzes, o erro e a mentira são produtos das idéias eclesiásticas, místicas e tradicionais e das regras políticas do ilegítimo Antigo Regime. É hipócrita - conforme Rousseau - uma sociedade que mantêm acorrentados homens, que são, por natureza, livres e iguais. Também é hipócrita, nos termos de Kant, o velho dogmatismo que aprisiona a razão e a impede de assumir criticamente o conhecimento de si mesma e, assim, garantir suas legitimas pretensões de verdade. A hipocrisia decorrente das antigas formas de saber e de poder é superada através da afirmação do conhecimento científico e da racionalização da vida social e política. No novo mundo idealizado pelos iluministas reina a razão, a verdade e a transparência, e não há lugar para a hipocrisia.

\section{Saber e hipocrisia}

O breve e precário mapeamento das noções de hipocrisia acima delineado conduz ao paradoxo que, grosso modo, pode ser colocado nos seguintes termos: o objetivo de buscar a verdade justifica a necessidade de acreditar na possibilidade de encontrá-la e de refutar as dúvidas acerca desta possibilidade; a busca, para assegurar a certeza, é dirigida para a verdade absolutamente certa e universalmente aceita; o que, por sua vez, exige a utilização de critérios verdadeiros para evitar equívocos na arte de distinguir a verdade do erro. Se as verdades descobertas são absolutas e universais, as idéias que as contrariam são falsas e devem ser combatidas e eliminadas a bem da verdade. Mas se estas verdades consideradas absolutas e verdadeiras não forem o que pensam que são? A possibilidade deste equívoco é indicada pelo fato de muitas delas terem deixado posteriormente de ser aceitas como verdadeiras. Quando isto ocorre, revelam o erro daqueles que as produziram, ou a impossibilidade uma verdade absoluta e universal? Se as verdades encontradas fossem efetivamente absolutas e universais, elas não demonstrar-se-iam no tempo quiméricas. Se elas demonstraram-se quiméricas, é porque mentiam. Mas a 
busca da verdade não tem por objetivo primeiro evitar a mentira. A verdade não é por definição o contrário da mentira ? Então, por que em busca da verdade se produz hipocrisia?

Tais indagações remetem à reflexão sobre o significado deste processo. Seu ponto de partida é a afirmação da concepção de Platão e de Aristóteles de verdade absoluta e universal, reposta pelo movimento iluminista, na forma de objetividade cientifica, e pelo pensamento político e sociológico posterior marcadamente racionalista e cientificista. Os questionamentos sobre a possibilidade de conhecimento da verdade e sobre a relação verdadeiro/falso dos sofistas, dos cínicos e dos cépticos mantiveram-se marginais em relação às tendências predominantes do pensamento moderno. Eles foram rechaçados e desautorizados como legítimos na medida que a pretensão de verdade absoluta de um saber dominante o leva a negar e caracterizar como falsas outras formas de saber diferentes. Isto se expressa na linguagem: sofismar adquire o significado de deturpar os fatos, burlar, enganar com argumentos falsos aparentemente verdadeiros; o termo cínico passa a ser utilizado para designar indivíduo sem escrúpulos, hipócrita, sarcástico e oportunista. O mesmo ocorre com Maquiavel, não por sua concepção de verdade, mas pelo conteúdo atribuído a ela (verdades que não podiam ser afirmadas enquanto tais): torna-se corrente o sentido vulgar de maquiavelismo como procedimento astucioso, velhaco, traiçoeiro, ardiloso, pérfido e hipócrita.

A hipocrisia é atribuída aos que discordam das verdades consideradas inquestionáveis: os sofistas que possuem outra concepção de verdade, os demagogos que sustentam valores políticos considerados inadmissíveis, os cínicos que se opõem ao pensamento dominante com sua filosofia anti-convencionalista, os maquiavélicos que expõem as entranhas do poder e a lógica do jogo político. $\mathrm{O}$ caráter hipócrita destes agentes é explicado através de argumentos de corte essencialista: o sofista é por natureza um falso sábio, o cínico é por definição dissimulado, o maquiavélico é logicamente mal intencionado. A hipocrisia é vista como produto dos vícios e das imperfeições da natureza humana. Pensadores iluministas, na mesma perspectiva de Maquiavel, politizam a questão, atribuindo à ação hipócrita motivos decorrentes de interesses e do jogo de poder. Contudo, negligenciam o problema quando consideram que tais interesses produzem hipocrisia porque são retrógrados, representam forças políticas e idéias ultrapassadas. Acreditam na ilusão da transparência de um regime fundado nas leis e da capacidade do saber conduzir os homens à verdade e à liberdade.

A incessante procura da verdade e a crença na possibilidade de conhecê-la não impediram que as verdades descobertas, tidas como absolutas, eternas e univer- 
salmente válidas, fossem posteriormente questionadas e consideradas falsas, e perdessem completamente a sua aceitabilidade. A pretensão de verdade absoluta, de validade universal e de eternidade de um conhecimento engendra um movimento de dogmatização que limita crescentemente a sua capacidade explicativa e expande, na mesma medida, a sua potencialidade hipócrita.

Um saber que se auto-define como absolutamente verdadeiro torna-se hipócrita, por várias razões, dentre as quais destacam-se três. Em primeiro lugar, porque nega a pluralidade do conhecimento. Por considerar-se a única forma aceitável de saber, àquela que produz a verdade absoluta, desautoriza a legitimidade das outras formas de saber existentes. Esconde, assim, o seu caráter parcial de ser uma entre várias formas possíveis de saber. Atribui a si o direito de dar o veredicto sobre o que é certo e errado, desconsiderando a possibilidade do seu próprio erro. A reflexão que Foucault faz a partir de Nietsche, interroga se a refutação de erros feita em nome da verdade não é a história de um erro que tem o nome de verdade, e se o que é considerado verdade não é uma espécie de erro que tem a seu favor o fato de não poder ser refutado(Foucault, 1981).

Em segundo lugar, um saber que se arvora à condição de verdade absoluta é hipócrita porque nega a relatividade do conhecimento e desconsidera os seus próprios limites, histórica e socialmente condicionados. Afirma ser universal e absoluto um conhecimento limitado e relativo ao seu tempo e a sua sociedade. Como diz Foucault, "cada sociedade tem o seu regime de verdade", isto é, o conjunto de regras através das quais distingue o que considera falso e verdadeiro. As verdades descobertas não são produto de "essências", "realidades transcendentes", elas são deste mundo, são criadas pelos homens, e correspondem à "política geral de verdade" de cada sociedade: "os tipos de discurso que ela acolhe e faz funcionar como verdadeiros; os mecanismos e as instâncias que permitem distinguir os enunciados verdadeiros dos falsos, a maneira como se sanciona uns e outros; as técnicas e os procedimentos que são valorizados para a obtenção da verdade; o estatuto daqueles que tem o encargo de dizer o que funciona como verdadeiro"(Foucault, 1981).

Em terceiro lugar, a verdade existe socialmente associada à mecanismos e relações de poder. Ela "está circularmente ligada a sistemas de poder, que a reproduzem e apoiam, e a efeitos do poder que ela induz e que a reproduzem"(Foucault, 1981). A verdade é produzida através de coerções que afirmam o saber definido como verdadeiro e excluem outras formas de saber. E ela também produz efeitos de poder, na medida em que autoriza os discursos verdadeiros, em função dos quais 
os homens são prestigiados ou desvalorizados, julgados e condenados. Todo exercício do poder supõe a produção de discursos de verdade, que justifiquem as regras (jurídicas, políticas) de regulamentação da ordem social, e garantam o seu funcionamento. Para exercer este papel, no entanto, a verdade é obrigada a mentir. Ela precisa negar o seu caráter monopólico, aparecendo como naturalmente a única; negar a sua capacidade de, produzir sanções, em defesa de si mesma, para excluir idéias distintas; negar o seu inevitável vínculo com o poder, a relação de poder que ela supõe, os seus efeitos de poder, e a hipocrisia contida nas relações de poder. A verdade não pode aceitar que ela mesma carrega hipocrisia. Assim, precisa dissimular o seu caráter hipócrita.

Portanto, a abordagem do problema da hipocrisia requer uma alteração dos termos da discussão. Não se trata de buscar identificar aquelas ações e aqueles agentes que fraudam uma verdade universalmente válida, evidente ou acessível, compartilhada por todos. As verdades são limitadas, relativas e definidas socialmente por um regime que supõe e produz poder. A fraude não pode ser explicada pela natureza do agente mas pela natureza das relações e da estrutura de poder. Embora todos estejam submetidos às regras deste regime de verdade e às coerções daí decorrentes, os comportamentos e as posturas assumidos frente a elas são diferenciados. Há resistência nas relações de poder e há pluralidade na interpretação acerca das verdades socialmente produzidas. Os agentes se movem no complicado terreno do poder de modo a tentar afirmar as suas verdades frente às verdades socialmente estabelecidas. O melhor modo de operar neste terreno, recomenda a razão política, é distinguir verdades sociais elaboradas na forma de discurso público e verdades que devem ser mantidas circunscritas ao âmbito da reflexão privada. O ocultamento de certas verdades garante maior eficácia na ação política.

Convém aos agentes não explicitar aquelas verdades cujo conhecimento público produziria resultados distintos dos desejados. Isto diz respeito às verdades consideradas socialmente ilegítimas (como, por exemplo, o desejo de beneficiar a si próprio ou ao grupo através da uso do poder publico) e todas aquelas utilizadas para maximizar a ação. Isto é, aquelas que possibilitam ao agente defender de modo mais eficiente os seus interesses e valores, obter ganhos e conseguir derrotar os adversários, alterar as relações de força, ampliar e conservar poder através de regras e técnicas eficientes. Vale, sobretudo, o cálculo político sobre as vantagens de omitir, negar e dissimular o que é tido como verdade. É preferível mentir do que enfrentar situações indesejadas, cujos resultados podem ser prejudiciais. Grande parte das pessoas costuma mentir e esconder seus verdadeiros sentimentos, pois a total liberdade de expressão é vista como uma impossibilidade social. Desde cedo 
os indivíduos apreendem a dissimular, dizendo aos outros o que eles querem ouvir. Para a maioria isto é natural, pois é inútil discutir idéias e valores socialmente aceitos. Intimamente "acreditamos no que queremos acreditar", mas, "externamente usamos uma máscara" (Greene, 2000). Muitas vezes, usar mascaras e dissimular parece para o agente uma imposição. Mentir parece ser a única alternativa para quem infringiu gravemente as regras do jogo e corre o risco de ser punido. Em defesa de si próprio, o agente esconde elementos do que considera verdade para responder "adequadamente" às obrigações impostas pelas tradições e relações sociais e sistemas de poder.

A operação hipócrita consiste em uma exteriorização discursiva que omite ou nega parcial ou totalmente certas verdades internas, para que elas mesmas, transformadas, maquiadas ou disfarçadas através de recursos da racionalização, orientem efetivamente o sentido da ação e os seus resultados. O agente oculta o que considera verdade tendo em vista os resultados que poderá obter com esta operação no jogo de poder.

A hipocrisia, portanto, não pode ser considerada simplesmente produto de uma ação deliberadamente mal intencionada de agentes. Ela é socialmente produzida e está ligada às regras e estruturas de poder. $\mathrm{O}$ agente torna-se hipócrita na medida em que busca tornar sua ação mais eficaz e responder adequadamente as demandas do jogo do poder. Quem não segue as regras hipócritas deste jogo é punido, isolado, neutralizado ou eliminado.

\section{Hipocrisia como relação de poder}

A hipocrisia está ligada a sistemas de poder que ela produz e sustenta e tem como efeito instituir ou conservar relações de poder. A ação hipócrita opera como forma de poder: seja como forma defensiva de reação do agente às obrigações das estruturas de poder, seja como forma ofensiva de subjugar ou de obter ganhos. Somente será eficaz a ação hipócrita que não for percebida enquanto tal. Se uma mentira não parecer verdade aos olhos do interlocutor ela, enquanto mentira não terá a eficácia desejada. Se um agente for percebido como hipócrita ele não mais terá crédito para proceder deste modo. A operação hipócrita depende, assim, para não ser frustrada, de uma certa competência, que diz respeito a saber e poder. $\mathrm{O}$ agente necessita ser protegido por sua posição que permite ocultar e transformar informações e pela assimetria de saberes. Maior eficácia está associada às condições de reduzir a visibilidade da sua ação hipócrita através do controle e da obstrução de informações e da opacidade do poder. O uso de técnicas hipócritas e a 
dissimulação permanente possibilita a formação de um certo saber, de circulação restrita, que, por sua vez, assegura o exercício do poder.

O poder não deve ser considerado somente como força, coação, repressão, mas também como forma de desarmar, desmobilizar, seduzir, aliciar, produzir corpos dóceis (Foucault, 1984). Mesmo quando o elemento força é preponderante, há um discurso de legitimação. Como afirma Bourdieu, "todo exercício da força se acompanha de um discurso visando legitimar a força de quem o exerce; podemos mesmo dizer que é próprio de toda a relação de força só ter toda a sua força na medida em que se dissimula como tal"(Bourdieu, 1983). Se as relações de força não fossem dissimuladas por um discurso de legitimação, se elas fossem percebidas tais como realmente são, elas perderiam a sua força na medida em que deixariam de ser relações socialmente aceitas. Elas somente existem e se mantêm porque escondem a sua natureza e se dissimulam.

A ilusão - lembra Bourdieu - não é ilusória, pois não se pode desconsiderar que os sujeitos sociais agem de acordo com as suas representações do mundo social e político(Bourdieu, 1983). A representação subjetiva dos agentes sobre o que seja real e verdadeiro orienta a definição da sua ação no jogo político. Conforme o que for considerado verdade pelos agentes pode-se manter ou alterar relações de força, conservar ou derrubar governos.

Por esta razão, a verdade é objeto de luta. Dependendo do que for considerado verdadeiro haver uma determinada configuração da correlação de forças. Através de uma disputa encarniçada, os agentes buscam fazer valer as suas verdades no processo de definição do que deve ser considerado verdade. Trata-se de um permanente combate que pode ser comparado, analogamente, à luta militar. A "política" - afirma Foucault, invertendo Clausewitz - "é a guerra prolongada por outros meios"(Foucault, 1981). Os diferentes agentes se enfrentam nesta guerra silenciosa sublimada buscando defender seus interesses e obter ganhos. A eficácia da sua ação é definida por sua capacidade de impor derrotas aos adversários. Enganar, dissimular, confundir, mentir, induzir ao erro, iludir ou cooptar os adversários constituem instrumentos habituais nesta luta.

As táticas e estratégias de ação da experiência militar são paradigmáticas para se pensar a eficácia instrumental do recurso hipócrita. As manobras e estratagemas utilizadas são mais úteis quanto mais astuciosas na sua capacidade de enganar e surpreender o inimigo. Infiltrar espiões, divulgar informações falsas, corromper, pagar delatores, forçar traições, realizar sabotagens, são instrumentos utilizados e considerados válidos para os fins de êxito. Inclusive, um meio cruel como a tortura 
é justificado em situações de guerra com o argumento de que é preferível o sofrimento de um inimigo do que a morte de milhares de aliados que poderia ser evitada com as informações obtidas.

O recurso hipócrita faz parte do arsenal utilizado nas relações entre os que estão do mesmo lado da trincheira. É o caso do comandante que se encontra em uma situação adversa, com pequenas possibilidades de vitória em uma guerra que ser desgastante, penosa e longa. Para evitar a desmobilização da tropa, e encorajála para a luta, oculta a situação real e engana os soldados, dizendo a eles que esta batalha é a ofensiva final, em seguida será conquistada a paz. Mentir é igualmente considerado necessário no caso do anti-herói bem sucedido: aquele que precisa esconder suas covardias, pois não há lugar para elas em uma cultura militar que tem no heroísmo seu símbolo de virtude. Se as assumisse publicamente, seria desprezado, e teria sua influência reduzida ou anulada na estrutura de poder da instituição. Deste modo, ele é levado a alquimia hipócrita de ocultar suas covardias e mascará-las, tornando-as imperceptíveis e transformando-as aparentemente em atos de heroísmo.

O mesmo se observa no campo da política institucional e partidária. A proximidade entre o modelo militar e o partidário é muito grande. Militar (do latim militare, de miles Bitis "soldado")significa tanto fazer guerra, combater, como ser membro de um partido e agir politicamente através do partido. É por isto que são usadas as expressões "militância partidária" (os que combatem pelo partido, militam pela causa) e "soldado do partido" (o militante se submete às decisões da direção partidária). Nos dois casos, grupos organizados se enfrentam. A principal diferença refere-se às armas utilizadas. Ao invés das armas de extermínio físico da guerra são utilizadas pelos partidos e militantes as armas de desgaste e extermínio político: os argumentos que buscam convencer os eleitores como os adversários estão associados à produção de prejuízos e como as propostas defendidas são melhores e imprescindíveis para resolução dos problemas coletivos. O extermínio político significa desgastar a imagem dos adversários até provocar a completa eliminação da sua credibilidade.

A operação hipócrita é usualmente utilizada nos processos de fortalecimento artificial de uma proposta (fazer parecer que ela possui uma aceitação muito superior a que realmente tem), de responsabilização indevida dos adversários por problemas graves que causam prejuízo a todos, de utilização de fatos conjunturais para desgastar outros setores políticos, de incentivo ao recrudescimento de uma crise visando enfraquecer o grupo no poder e fortalecer a si e ao seu grupo como 
alternativa política. Como na guerra, no combate político são utilizados todos os recursos disponíveis para fragilizar o adversário. São muito utilizadas as táticas de distorcer fatos para desgastar a imagem do candidato do partido oponente, de fazer denúncias, com base em situações forjadas, tentando divulgar a idéia de falta de honestidade e probidade administrativa do concorrente, de acusar o adversário de não ter cumprido sua palavra, e assim por diante. São comuns as acusações recíprocas de hipocrisia.

O jogo de enganar os outros para obter vantagens ou alterar relações de força também está presente nas relações entre os membros de um mesmo partido. É o caso de um dirigente político que manipula informações utilizando indevidamente as possibilidades abertas pela privilegiada posição de representante ou de canal de comunicação entre instâncias políticas distintas. Ele apresenta uma proposta sua como sendo uma demanda da base que representa em um organismo de direção, ou apresenta sua proposta como sendo a da direção, e utiliza este "peso" de legitimação para convencer a base. A estrutura da instituição e a proximidade do tempo de discussão da proposta nas duas instâncias dificultam a visibilidade e protegem a operação hipócrita.

Muitos políticos e cientistas políticos criticam o uso de recursos hipócritas na atividade política. Percebem a hipocrisia como uma doença que pode e deve ser eliminada do jogo político. Acreditam na possibilidade do domínio da ética na política. Estão, deste modo, se referindo a uma política imaginada e não à política realmente praticada. A distância entre as intenções e a realidade da ação prática dos agentes políticos, entre os discursos e a atividade política é grande não por um problema pessoal relativo ao caráter dos políticos. Estes não agem livremente de acordo com as suas intenções e projetos, mas em um sistema político que possui regras e em condições que eles não determinam. Entre as regras do jogo político, há a necessidade de eficácia. Se um agente político não for eficaz ele será eliminado do jogo, será um profeta desarmado, vencido, fracassado. Ele precisará agir, em determinadas circunstâncias, de forma dissimulada, deixando de cumprir certas promessas, modificando oportunamente o seu ponto de vista. Precisará agir de forma hipócrita, mas sem ser visto como tal. Necessitará parecer integro, sincero e totalmente ético. Mas se agir sempre conforme esta aparência isto causará a sua ruína. O que impossibilita a política ética não é a falta de intenção ou vontade, mas o problema da eficácia. $\mathrm{O}$ agente ético é totalmente previsível e facilmente será vencido no jogo político. $O$ fato dos políticos defenderem uma política ética é compreensível: eles precisam ser vistos como éticos para manter e ampliar a sua credibilidade. 
Mas o dever do cientista político é analisar a realidade tal como ela realmente existe e não alimentar crenças e ilusões politicamente desejáveis.

A hipocrisia, portanto, está visceralmente associada ao poder. Ela não é um vício eliminável, mas um instrumento eficaz que assegura poder. Sua existência deve-se a sua utilidade no jogo de poder. O agente que a realiza a operação hipócrita de modo eficiente maximiza a sua ação neste jogo. A hipocrisia constitui uma forma de poder que produz poder, do mesmo modo que ela é necessária para o exercício do poder. Discursos hipócritas são utilizados nas relações de poder porque eles precisam esconder a natureza destas relações e apresentá-las como legítimas. Tais discursos são argumentos racionais. O exercício do poder implica na utilização de formas de racionalidade que justificam o uso do recurso hipócrita e que são, elas mesmas, hipócritas porque negam o caráter hipócrita das relações de poder.

\section{Razão e hipocrisia}

A razão política recomenda a utilização do recurso hipócrita na medida em o considera um instrumento eficiente para a obtenção de ganhos no terreno das relações de poder. A razão política é demagógica no sentido pejorativo atualmente empregado ao termo: aplicar mentiras e prometer o que não pode ser feito constituem um meio eficaz para maximizar a ação política, uma vez que existam condições para encobrir, através de justificativas, as mentiras ditas e para impedir a visibilidade da trajetória do comportamento político. $\mathrm{O}$ agente que consegue tornar imperceptível a simulação do seu comportamento é recompensado no jogo do poder. Embora seja um estímulo para ele continuar a esconder suas opiniões e buscar enganar os outros, isto também produz conflitos, na medida em que a ação hipócrita é condenada pelos valores morais socialmente aceitos que ele mesmo defende publicamente.

A hipocrisia é justificada racionalmente, no plano da reflexão privada, como um "mal necessário". Isto é, como um meio necessário para a realização de fins desejados. É a lógica de que os fins justificam os meios, caracterizada por Habermas como uma forma de "razão instrumental"(Habermas, 1989). Weber chama a atenção para os riscos desta lógica dos objetivos finais: a consecução de fins bons é limitada pelo preço dos meios moralmente dúbios que podem conduzir a ramificações daninhas(Weber, 1971). Há uma interdependência entre meios e fins, de modo que meios considerados "maus" podem conduzir a fins da mesma natureza. Meios podem moldar fins, assim como certos fins podem ser meios para outros fins e certos meios podem ser transformados em fins. 
A razão partidária constitui um tipo de racionalidade política, cuja tendência é transformar o partido, originalmente concebido como meio de afirmação de um projeto político, em fim da ação política por ele desenvolvida. A partir do movimento de auto-valorização que pode ser caracterizado como bazófia do partido, a agremiação cultua um amor excessivo a si mesma, passando a operar, segundo a lógica narcísica, em função do interesse próprio, de modo arrogante e particularista, fomentando a relação hobbesiana de busca incessante de poder e de subordinação dos interesses dos outros ao seu.

Nesta perspectiva, o partido tende a utilizar a lógica maniqueísta: se auto-define como bem intencionado, aquele que pretende fazer o bem, a justiça e o bom governo, e considera aqueles que se contrapõem às suas propostas e às ações partidárias como agentes do mal, que provocam a injustiça, a infelicidade e a desgraça da sociedade. De acordo com esta concepção essencialista, aqueles que estão do lado do bem não são hipócritas, pois no bem não há hipocrisia. Se houver, a hipocrisia é identificada em agentes que devem ser eliminados (o mal infiltrado no bem, como um câncer que deve ser extirpado) ou a utilização do recurso hipócrita pode ser justificada instrumentalmente, como meio para vencer o mal.

Perseguindo os seus próprios interesses e fins de êxito eleitoral e de ampliação do seu poder na estrutura política, os partidos utilizam, como recomenda a lógica instrumental, meios que consideram eficientes, como a modificação e adaptação dos seus programas para atrair e conquistar parcelas mais amplas do eleitorado. Deste modo, abandonam ou relativizam os seus princípios programáticos, aqueles que correspondiam à finalidade da sua existência, e afirmam os seus interesses imediatos, de acordo com as demandas do jogo do poder.

Internamente no partido opera-se um processo de oligarquização do poder e burocratização. As pessoas que ocupam cargos políticos acumulam poder, que possibilita o seu fortalecimento, assim como os grupos que dividem a direção política. Em nome do partido ou da causa, os agentes produzem discursos convincentes que mascaram os objetivos específicos de suas ações de acumular e ampliar poder. Os grupos dirigentes e funcionais se fortalecem, formando castas burocráticas, encasteladas no poder, que gozam de prestígio e privilégios. Utilizam argumentos racionais aparentemente legítimos, relacionados com as causas originais do partido, para o fortalecimento de poder pessoal e de grupo. Os grupos internos dominantes politicamente realizam uma disputa, vista como saudável e revigorante, feita em nome de princípios e idéias, mas que visa o estabelecimento da relação de forças do período e da divisão dos cargos políticos. Esta disputa, em parte formal 
e em parte real, também é utilizada como guerra santa, para a eliminação dos adversários internos considerados indesejáveis.

A razão de Estado também opera com uma lógica narcísica, maniqueísta e instrumental voltada para o fim de fortalecimento do Estado. Apoia-se na bazófia do Estado, e na idéia de que os seus interesses, identificados como correspondentes ao bem, devem ser defendidos de todas as formas e a qualquer custo. Assim, esta razão sustenta que é necessário utilizar o conhecimento racional, meios e técnicas eficazes para preservar e expandir o Estado, para derrotar, conter ou anular seus inimigos e garantir o seu bom funcionamento. A segurança e os interesses do Estado são considerados exigências que justificam a violação das leis e normas jurídicas, políticas e morais. O recurso hipócrita é considerado um meio válido para a defesa dos interesses estatais. Organismos como os serviços de informação e de inteligência têm por dever profissional a função de ocultar certas verdades, manter segredos de Estado, e divulgar versões consideradas falsas sobre acontecimentos e fatos políticos que podem produzir efeitos tidos como prejudiciais.

A razão política restrita à racionalidade meio-fim despreza os princípios e valores éticos em favor da eficiência e do êxito. Deste modo, torna-se serva do poder. Opera como prisioneira da lógica do jogo do poder e tem por função fornecer os argumentos racionais necessários para a legitimação deste jogo. Todo exercício de poder requer discursos racionais, assim como todas as relações de poder são racionalizadas. As formas de racionalidade utilizadas escondem o caráter hipócrita das relações de poder. Os meios e técnicas hipócritas correspondem a um certo saber necessário ao exercício do poder. A hipocrisia realiza-se como operação através de formas de racionalidade instrumental que se tornaram dominantes no mundo contemporâneo.

A tendência à burocratização do Estado e da empresa capitalista e o processo de secularização - apontados por Weber - correspondem ao avanço da razão instrumental que resulta na perda da liberdade do homem. A eficiência e o êxito desejados tornam-se quiméricos, uma vez que os meios adotados pela razão instrumental não são orientados por princípios éticos. A lógica cega da burocracia e razão racionalista cientifica produzem grandes irracionalismos, extremamente perigosos aos homens, como as grandes armas de aniquilação que podem destruir o planeta.

Habermas opõe à razão instrumental, voltada para o sucesso, e radicada na esfera sistêmica, a razão comunicativa, voltada para o entendimento mútuo, e situada na esfera do mundo vivido. A racionalidade comunicativa se expressa nas 
interações através das quais as pessoas envolvidas entram em acordo para coordenar os seus planos de ação, através do debate sobre as pretensões de verdade em relação as proposições relativas ao mundo objetivo das coisas, ao mundo social das normas e ao mundo subjetivo das vivências e emoções. Trata-se de uma razão ética. $\mathrm{O}$ debate entre os agentes é orientado pelos seus valores éticos e a validade de uma proposição é definida no processo de argumentação e de contra argumentação que visa o entendimento mútuo(Habermas, 1989).

Com o conceito de razão comunicativa Habermas procura mostrar que não há uma crise da razão de modo geral, mas a crise de uma forma de racionalidade instrumental, comprometida com o poder e com a miséria humana. No se entender, a razão comunicativa mantém a sua validade e potencialidade crítica. É um tipo de razão ética que jamais aceitaria o uso de bombas atômicas ou quaisquer outros instrumentos que possam causar prejuízos irreparáveis à humanidade. Uma razão comunicativa não seria hipócrita na medida em que define o que considera verdade por consenso e não utiliza esta verdade como forma de poder.

Foucault, diferentemente de Habermas, não busca fundar um novo racionalismo. No seu entender, não se trata de libertar a verdade do poder - o que seria quimérico, na medida que a própria verdade é poder - mas de mostrar o poder da verdade nas formas como se realiza nas instituições (não só nas estritamente políticas) e nas práticas sociais. Isto é, questionar as formas de racionalidades envolvidas em todos as esferas de exercício de poder e mostrar o modo como as relações de poder são racionalizadas(Foucault,1990).

A estratégia discursiva de Habermas de crítica à razão instrumental e resgate de uma forma de racionalidade comunicativa e ética, é vulnerável. Pode-se indagar: Quais são as condições sociais necessárias para a afirmação de um novo tipo de racionalidade como este? É possível que a racionalidade comunicativa venha a substituir a razão instrumental ou, ao contrário, é mais provável que a racionalidade sistêmica expanda-se cada vez mais, tornando cada vez mais escassos os espaços da razão comunicativa? A esfera política, por suas próprias características, não se coaduna mais com uma lógica do tipo instrumental do que com uma do tipo comunicativa? Se uma forma de racionalidade comunicativa se tornasse hegemônica em uma esfera como a política, ela não se modificaria de acordo com as demandas do jogo do poder? A razão instrumental se afirma pela eficácia. A razão ética é tentadora como utopia, discurso aceitável do mundo imaginado como melhor. Ela é sedutora como argumento visando conquistar simpatias e apoios mas conduz ao fracasso se for encarada como regra de ação única e permanente. 
Os argumentos de Maquiavel e de Foucault nos privam da desejada utopia de um mundo político melhor, mas são mais realistas, e estão mais de acordo com os deveres do cientista político. Nos mostram que vencem os agentes que utilizam formas de racionalidade adequadas, discursos convincentes de acordo com os valores socialmente aceitáveis e práticas políticas eficientes. Agentes que parecem ser totalmente éticos, mas, que sabem, nas circunstâncias necessárias, agir de modo diverso, racionalmente eficaz, obtém vantagens no jogo do poder.

\section{Considerações finais}

A reconstituição da noção de hipocrisia, desde os escritos antigos até o pensamento moderno, mostrou a história de uma disputa que entrelaça saber e poder. Tornou-se dominante no pensamento contemporâneo a idéia das tradições platônica, aristotélica, iluminista, racionalista e cientificista, segundo as quais, hipocrisia corresponde a ação deliberadamente mal intencionada que frauda uma verdade universalmente válida, evidente ou acessível, compartilhada por todos. Esta concepção obscurece o problema da hipocrisia, pois desconsidera que as verdades produzidas são limitadas, relativas e definidas pelas regras do regime de verdade e do sistema de poder de uma sociedade.

Também tornou-se dominante a idéia de que o problema da hipocrisia não é digno de ser estudado, por representar uma imperfeição da natureza humana que deve ser corrigida, um problema de menor importância, uma excrescência, uma doença que pode e deve ser eliminada do jogo político. Os pensadores políticos preferiram refletir sobre a política imaginada, dos governantes sábios e bem intencionados, voltados para a promoção do bem e da felicidade, e sobre os fundamentos da obrigação política que poderiam ser aceitos como legítimos.

A reflexão contemporânea sobre os limites da razão científica e sua pretensão auto-idealizada de método único de obtenção da verdade possibilita a valorização de análises realistas, como a de Maquiavel, e críticas da razão política, como a de Foucault. O olhar realista sobre a natureza do poder político permite atribuir a devida importância ao problema da hipocrisia como elemento constituinte das relações políticas. Os recursos hipócritas dos agentes políticos não são produto das imperfeições da natureza humana, não são problemas exclusivamente morais, não são tumores que possam ser extirpados.

A fraude, a mentira, a dissimulação, a indução ao engano, fazem parte do jogo político e das relações estabelecidas pelos agentes. São produzidas socialmente por um regime que supõe e produz poder. Constituem instrumentos extremamente 
importantes para viabilizar o êxito político. São meios eficientes para assegurar e ampliar poder. São instrumentos recomendados pela razão instrumental uma vez que produzem inegável vantagem sobre os adversários políticos.

Todo exercício de poder requer discursos racionais que o legitimem. As formas de racionalidade utilizadas buscam, de um lado, assegurar a aceitação do agente político, produzindo argumentos, propostas, projetos em conformidade com os valores, crenças, desejos e expectativas da sociedade. Os agentes políticos conseguem assegurar e ampliar poder quando as suas idéias e imagem são percebidas positivamente, produzindo identidade e aceitabilidade. De outro lado, movimentam-se lucidamente no jogo político os agentes orientados pela racionalidade instrumental, que sabem utilizar os meios mais adequados para os fins propostos. Enganar o adversário, induzindo-o ao erro, constitui um recurso poderoso no jogo do poder.

Assim, parecer sincero e ético, mas agir de modo diverso, possibilita o fortalecimento político. Contudo, se o agente não for eficiente na sua dissimulação, perderá a credibilidade e o poder conquistados. O risco de ser desmascarado não inibe a iniciativa hipócrita, uma vez que o agente acredita no seu desempenho e nos benefícios que irá obter como produto de sua ação. A opacidade do poder e a assimetria de saberes específicos também são fatores encorajadores. A eficácia instrumental do meio conduz o agente a sua utilização, em maior ou menor medida, de acordo com as circunstâncias e necessidades.

Nesta perspectiva, a desejável ética na política não faz parte da natureza do poder político. Como valor socialmente aceito e utopia querida, faz parte das estratégias discursivas utilizadas pelos agentes políticos para conquistar simpatias e adesões. Mas, na política efetivamente praticada, as ações éticas não são dominantes e, muitas vezes, estão associadas aos insucessos ou à produção de fatos simbólicos relevantes para a construção, alteração ou reposicionamento da imagem dos agentes.

\section{Bibliografia citada}

ARISTÓTELES. Política. Brasília. Ed. Universidade de Brasília. 1985.

ARISTÓTELES. Dos Argumentos Sofísticos. In: Os Pensadores. Abril. 1973.

ARISTÓTELES. Ética a Nicômaco. Atena Ed. 1959.

BOUDIEU, Pierre. A opinião pública não existe. Questões de Sociologia. Rio de Janeiro. Marco Zero. 1983. 
BOUDIEU, Pierre. Uma ciência que perturba. Questões de Sociologia. Rio de Janeiro. Marco Zero. 1983.

FOUCAULT, Michel. Microfísica do Poder. Rio de Janeiro. Graal. 1981.

FOUCAULT, Michel. OMNES ET SINGULATIM: POR UMA CRÍTICA DA 'RAZÃO POLÍTICA”. In: Novos Estudos CEBRAP, número 26, março de 1990.

FOUCAULT, Michel. Vigiar e Punir. Petrópolis. Vozes. 1984.

GREENE, Robert. As 48 leis do poder. Rio de Janeiro. Rocco.2000.

HABERMAS, Jurgen. Consciência Moral e Agir Comunicativo. Rio de Janeiro. Tempo Brasileiro. 1989.

HOBBES, Tomas. Leviatã ou matéria, forma e poder de um Estado eclesiástico e civil. Os Pensadores. Abril. 1974.

MAQUIAVEL, Nicoló Di Bernardo. O Príncipe. Rio de Janeiro. Civilização Brasileira. 1976.

PLATÃO. A República. São Paulo. Atena. 1946.

PLATÃO. Hípias Menor. In: Diálogos. Gráfica e Editora Universitária. Universidade Federal do Pará. 1986. Vol.XI.

PLATÃO. Sofista. Globo. 1961. Vol.II.

WEBER, Max. Ensaios de Sociologia. Rio de Janeiro. ZAHAR.1971. 